\title{
Guest Editorial: Trade and Transportation Facilitation
}

\author{
Peter J. Rimmer*
}

\section{INTRODUCTION}

International trade and transportation should go hand-in-hand. As demonstrated by the European Union (EU), the North America Free Trade Agreement (NAFTA) and the Association of Southeast Asian Nations (ASEAN), efforts to facilitate cross border trade have to be underpinned by improvements in international logistics. Indeed, trans-border corridors in Canada, the United States and Mexico were unprepared to accommodate the sharp increase in border crossings that stemmed from the development of border-spanning industrial complexes triggered by NAFTA after 1994 (Bradbury, 2002, 2003a,b). Delays and congestion occurred as the north-south corridors became as important as the traditional east-west trade routes. This outcome underlines the importance of integrating related policy areas such as trade and transportation.

In some respects, the EU was better prepared than NAFTA as transportation has been one of the key policy areas since the Treaty of Rome in 1954. Although free market access and interconnection across international frontiers was initially hindered by the unwillingness of national governments to transfer authority to the regional body, the position changed with the development of an internal market since 1993, especially in air transportation (Ross, 1998; Button, 2003). This provided the EU with the opportunity to develop a more appropriate framework for trade and transportation facilitation that is outlined in the WHITE PAPER: European Transport Policy for 2010: Time to Decide (DG TREN, 2001). ASEAN, since its inception in 1967, has also recognized transportation as one of the key catalysts of economic development and international competitiveness, as evident in a series of plans to support the ASEAN Free Trade Area (AFTA) established in 1992, including the updated ASEAN Transport Action Plan 2005-2010 (ASEAN, 2005).

Paradoxically, Northeast Asia has not followed the experience of ASEAN, the EU and NAFTA in seeking to facilitate trade and transportation through trading blocs. Although there are compelling economic arguments for moving towards a more liberal regulatory environment, there is no trilateral agreement between China, Japan and Korea. Even a bilateral agreement has yet to be forged, although an arrangement between Japan and Korea is under negotiation and may serve as a catalyst to the inclusion of China. Several historical, geographical, economic, political and social reasons have been proffered for this impasse. Rather than add to this list, perhaps the prime task is to suggest

\footnotetext{
* Hanjin Shipping Chair Professor of Global Logistics, Asia Pacific School of Logistics, Inha University and Visiting Fellow, Department of Pacific and Asian History, Research School of Pacific and Asian Studies, The Australian National University, Canberra, ACT 0200, Australia. E-mail:rimmer@inha.ac.kr
} 
which transportation modes offer the best prospects for streamlining efforts at integration between China, Japan and Korea once it is acheived. Shipping and air transportation are nominated because they can develop more rational networks to serve customers most efficiently (Oum and Lee, 2002). Effecting land transportation connections in Northeast Asia offer a greater challenge.

\section{TRADE, TRANSPORTATION AND THEORY}

The articles presented here make important contributions to either international trade or transportation within a Northeast Asian context. However, a concluding theoretical article holds promise of examining both trade and transportation facilitation under a single umbrella. This prospect should be seen as a desirable outcome of the various studies undertaken on international logistics or trade.

\section{Trade}

The first three of the four papers on trade stem from the New Vision for TransPacific Cooperation Conference held at Inha University on May 30 2005, which was sponsored by the Jungseok Research Institute. This Conference covered emerging patterns of Trans-Pacific economic relations. These papers on trade and foreign direct trade relations, determinants of capital flows and regionalism provided the background for those on revitalizing Trans-Pacific economic activities with contributions by speakers from Australia, Canada, China, Japan, Korea and the United States.

Moon-Soo Chung, Advisor to the President for Economic Policy, Republic of Korea, set the tone of the Conference and the two papers that follow in a lunchtime keynote address on economic cooperation for common prosperity in the Trans-Pacific region. As his contribution provides a succinct summary of fast expanding regionalization within an increasingly globalized world, it is reproduced here. This 'viewpoint' highlights changes in the world economy and future challenges, economic cooperation in the Trans-Pacific region, possible areas for future regional cooperation and Korea's role in strengthening economic cooperation in the Trans-Pacific. Of particular note, is the author's willingness to see the Trans-Pacific as a whole and to recognize the unrealised potential of the Asia Pacific Economic Cooperation (APEC) forum in providing a comprehensive system for regional economic co-operation. Joint efforts are needed to advance financial cooperation, capitalize on the potential of intra-industry trade, secure energy supplies and mitigate sharp difference between the rich and the poor. Korea is willing to play a key facilitative role in these endeavors.

Jaleel Ahmad from Canada's Concordia University in Montreal narrows the focus by

${ }^{1} \mathrm{~A}$ customs union is the grouping of countries with a common external tariff. However, there may be free trade and the free movement of capital and labour between them. 
providing an economic analysis of the key policy issues involved the proposed trilateral preferential trade area between China, Japan and Korea employing customs union theory. ${ }^{1}$ This theory examines the impact of trade in general after the removal of barriers, notably tariffs and quotas, between the three countries and their establishment against other countries. As there is already a well-established intra-regional trade between the three countries there may not be much benefit from new trade creation. According to the author, the real benefits will stem from the growth of intra-industry trade, particularly manufactured goods and components. While trade diversion is a real possibility, minimizing trade disruption with the rest of the world can arrest it.

Inkyo Cheong $(2005 \mathrm{a}, \mathrm{b})$ from Korea's Inha University in Incheon, as part of a more extensive interest on regionalism in East Asia, concentrates on evaluating the prospects of a United States-Korea Free Trade Agreement in terms of likely economic and noneconomic losses. Should an East Asian agreement eventuate, the United States, given its weakening political and diplomatic position in the region, may be excluded. Without the U.S., however, trade diversion is likely to occur and increasing trade conflicts are likely. Therefore, the United States, according to the author's emphasis on the importance of non-economic factors, should forge an agreement with Korea to guarantee its continued inclusion in East Asian regional integration. This conclusion puts pressure on the United States to activate and resolve the slow-moving formal and informal discussions with Korea. Conversely, Korea would benefit from avoiding any over dependence on China and Japan.

Konstantin Korevevskij from the Russia's Pacific State University of Economics, in Vladivostok did not participate in the New Vision for Trans-Pacific Cooperation Conference. However, his article extends the Conference's original scope by providing a rare insight into bilateral relations between Korea and Russia since 1988. His focus is on shifts in reciprocal trade and investment flows between the two economies from 1990 draws on a wide array of statistics. His particular concern is with removing political issues that hinder the deepening bilateral economic relations between Korea and the Russian Far East. These include the relatively high transportation costs between the two countries and the prospect of improvement with the development of the railway through North Korea to Russia.

\section{Transportation}

The two articles on transportation are drawn from the Incheon International Logistics Seminar in October 2004 organized by the Jungseok Research Institute. A major theme was the importance of short sea shipping (SSS) approaches as a strategy to underpin Incheon as a logistics hub. Particular reference was made not only to European and North American experiences but also to China, Japan and Korea. Two of these revised contributions are published here.

Peter J. Rimmer, a Visiting Fellow from the Australian National University now at Inha University, and Claude Comtois, from the University of Montreal in Canada, 
examine the transformation China's maritime geography. By comparing changes in both the extra-Asian and intra-Asian services of the state's leading liner shipping company, China Ocean Shipping Company (COSCO), between 1990 and 2000 the authors provide a springboard for considering their strategic implications of corporate restructuring and the company's response to external and internal challenges. In turn, this analysis provides the basis for defining short-sea shipping and for examining its relative merits.

Jess Browning from the University of Washington in Seattle narrows the area focus from China to the Yellow Sea region, which is destined to become a major arena of world trade. Looking ahead to the resultant burgeoning cargoes, he builds on an earlier contribution to focus on the need for China and Korea to support the anticipated activity with an integrated coastal shipping and inland transportation system focused on Incheon (Browning and Lee, 2004). In particular, he canvasses technological innovations to meet the need for a more competitive shipping industry and favours reconsideration of the "float-on float-off" (FLO/FLO) container barge carrier to offset the chronic under use of coastal and inland water transportation. The proposed technology will assist the decentralization of port activities, especially as the barge can act as a floating transhipment terminal.

\section{Theory}

As the global and regional economies become more integrated it is not sufficient to merely to facilitate trade and transportation. There will be a pressing need to develop innovative models to ensure trade and transportation networks offer customers improved service levels through enhancement of the supply chain.

Guojun Li from Xiamen University takes up the challenge by exploring new logistics features that appear in an enterprise's supply chain stemming from the adoption of innovative modelling (see also $\mathrm{Li}$ and Zhou, 2004). Initially, a logistics management model and an associated technical system are developed based on the ranking of logistics centers. Then innovative modelling is applied in the three stages of product's market life cycle - new product development, production processes and management - using the theory of "extenics' and 'matter-element models' as controls to enable companies to meet the demands of an agile supply chain. This innovative modelling process provides a competitive edge and, reportedly, boosts profits to meet customer demands most efficiently. The text is laced with specific company examples and two case studies are used to elaborate outcomes.

\section{REPRISE}

As the prospects for a more liberated trade system brighten in Northeast Asia the need for matching improvements in regional transportation intensify. This raises the need for considering how a regional transportation and trade facilitation (TTF) system can evolve a transparent and accountable decision-making framework in response to a multi-state, 
intra-regional agenda, accommodating international commerce, tariffs and trade. Starting from scratch, as recognized by T.R. Lakshmanan and William P. Anderson (2005) in the EU and NAFTA, is a key advantage, although any new institution will have to overcome artefacts stemming from the evolution of national transportation modes when seeking to reduce barriers to cross-border transit (Kim, 2004).

These physical or institutional barriers can be overcome by instituting an efficient transport governance system. The system, according to T.R. Lakshmanan (2001: 8), combines two elements that influence the speed, ease and costs of cross-border freight flows. They are: physical infrastructure covering both transport networks and facilities, and complementary information and telecommunications networks; and the transport institutions (or non-physical infrastructure) embodying the knowledge and competencies applied to physical networks, including how to transport and communicate in specific legal, economic, financial and political frameworks in different parts of the world and how these structures can be altered, under rapidly changing technical and economic conditions, to improve transportation and trade (Table 1).

Table 1: Components of Transportation and Trade Facilitation (TTF) System

\section{PHYSICAL INFRASTRUCTURE \\ - Transportation Networks and Facilities and Information and Communications Technology}

o Transport Subsystems

o Information Subsystems

\section{NON-PHYSICAL INFRASTRUCTURE}

- Transport Institutions (Knowledge and Competencies in Transport and Trade Facilitation)

\section{o Overall Governance of Transport and Trade Facilitation}

The economic institutions governing transport (e.g. economic regulation, and privatization of transport assets)

o Systems of Governance of Physical Flows

Rules governing cross-border flows (customs and other border inspections

\section{- Market Organizations}

\section{o Financial Coordination Systems}

New mechanisms for coordination across economies scattered over the globe

o Business Logistical Systems and Practices

Innovations that squeeze out time and cost delays from goods supply chain

Source: Based on Lakshmanan, 2001:8; Lakshmanan and Anderson, 2002: 3-5, 2005. 
Promoting an effective intermodal system can reduce physical infrastructural constraints impeding potentially effective transportation corridors through improvements to both transportation and information subsystems. Transport institutions cover, as detailed by T.R. Lakshmanan and William P. Anderson (2002: 3, 2005), cover: (a) the economic institutions governing transportation, notably economic regulation and privatization of transport assets; (b) rules governing cross border flows such as customs and other border inspections, and rules for size and weight of vehicles; (c) mechanisms for financial coordination across economies scattered over the globe; and (d) business logistical properties. As improvements to financial coordination systems and business logistics practices, involving service providers and the logistics workforce, are strictly matters of market organization, attention, according to Lakshmanan (2001: 9), needs to be concentrated upon: (a) the overall governance of transportation and trade facilitation through innovations in legal, institutional, regulatory and administrative frameworks governing cross border movements, including not only deregulation of transportation services and privatization of transport infrastructure but, as detailed by Lakshmanan (2001b: 9), removal of cabotage and other residual economic regulations, reform of the commercial legal framework, reinvention of the customs function, adoption of international standards and trade practices and development of dispute settling procedures; and (b) governance of physical flows across borders through changes in the multiplicity of rules governing customs and border inspections should land borders be eliminated. Given this agenda, there is great scope for work by both government and academia on the transportation and trade facilitation system in Northeast Asia, particularly to recognize the pivotal importance of logistics. 


\section{REFERENCES}

ASEAN (2005), ASEAN Transport Action Plan 2005-2010 (Appendix II provides a list of projects). http://www.aseansec.org/16596.htm

Bradbury, S. L. (2002), "Planning Transportation Corridors in Post-NAFTA North America," Journal of the American Planning Association, 68(2): 137-150.

http://www.tradecorridors.com/overview/publications/planning_transportation_corrido rs.pdf

Bradbury, S. L. (2003a), Planning Transportation Corridors in Post-NAFTA North America, unpublished paper presented at the Conference on 'Every City is a Border City': Trade Corridors Conference 2003.

http://www.tradecorridors.com/overview/publications/planning_transportation_corrido rs.pdf

Bradbury, S. L. (2003b), Planning Transportation/Trade Corridors. http:/www.tradecorridors.com/files/suanbradbury.pdf

Browning, J. and Lee Seung Hee (2004), "Short Sea Shipping and Innovations for Intermodal Container Logistics in Northeast Asia", Journal of International Logistics and Trade, 1(2): 25-53.

Button. K. (2003), "Implementation Process of the European Common Air Transport Market and the Common Air Policy," in Cho Lee-Jay and Kim Yoon Hyun (eds) Building an Integrated Transport Market for China, Japan, and Korea: Building a Regional Coordinating Institution, Honolulu, EWC-KOTI: 3-82

Cheong, Inkyo (2005a), "Evaluation of Recent Progress of FTAs in East Asia - a Korean Perspective", in Choong Yong Ahn, R.E. Baldwin and Inkyo Cheong (eds), East Asia Regionalism: Feasibilities and Challenges, New York, Springer: 39-61.

Cheong, Inkyo (2005b), "Estimation of Economic Effects of FTAs in East Asia - a CGE Approach," in Choong Yong Ahn, R.E. Baldwin and Inkyo Cheong (eds), East Asia Regionalism: Feasibilities and Challenges, New York, Springer: 145-162.

DG TREN (2001), WHITE PAPER European Transport Policy for 2010: Time to Decide, European Commission, Directorate General of Transport and Energy.

http://europa.eu.int/comm/dgs/energy_transport/index_en.html

Ji, Guojun and Zhou, Yan (2004), “Organizational Values as 'Attractors of Chaos': An Emerging Supply Chain Management Change Designed to Overcome Organizational Complexity," Journal of International Logistics and Trade, 2(1): 69-84.

Kim Tae-Seung (2004), 'A preliminary design for achieving transport market integration 
in Northeast Asia', in WEC/KOTI, A Design for Northeast Asian Transport Market Integration: The Cases of ASEAN and NAFTA, Honolulu, the East-West Center and the Korea Transport Institute: 139-162.

Lakshmanan,T.R. (2001), 'Integration of transportation and trade facilitation', in T.R. Lakshmanan, U. Subramaniam, W.P.. Anderson, (eds), Integration of Transport and Trade Facilitation, Selected Regional Studies, Washington, D.C., World Bank: 1-12.

Lakshmanan, T.R. and Anderson, W.P. (2002), Evolution of transport institutions that facilitate international trade, paper prepared for presentation at NSF-ESF STELLA Focus Group 5 Meeting, April 26-27.

http://66.102.7.104/search?q=cache0F0taByBcIJ:www.stellaproject.org/focusgroup5/ Brussel?Papers?Lakshmanan.doc+Transport+Governance\&hl+en\&ic+UTF-8

Lakhsmanan, T.R. and Anderson, W.P. (2005), Transport's role in the integration process, CEMT/OECD/JTRC/TRI(2004)6, Regional Round Table 134 (Thessalonki, Greece), Europe and Central Asia: Trade in Transport Services, Market Access and Trade Facilitation, Joint OECD/ECMT Research Centre, European Conference of Ministers of Transport.

Oum, T.H. and Lee, Y-H (2002), "The Northeast Asian Air Transport Network: Is There a Possibility of Creating an Open Skies in the Region?", Journal of Air Transportation Management, 8: 325-337.

Ross, J.F.L. (1998), Linking Europe: Transport Policies and Politics in the European Union, Westport, Praeger. 